\title{
Methods for the Screening and Treatment of Spinocerebellar Ataxias
}

\author{
Pushpendra Mani Mishra ${ }^{1}$, Dr. Vimal Kishor Singh ${ }^{2}$ \\ ${ }^{1}$ Department of Biotechnology, Delhi Technological University, New Delhi 110042, India
}

${ }^{2}$ Founder \& O/I, Stem Cell Research Laboratory, Department of Biotechnology, Delhi Technological University, New Delhi 110042, India

\begin{abstract}
Spinocerebellar ataxias (SCAs) are a heterogeneous group of inherited neurodegenerative disorders that occurs in autosomal dominant manner. The disease shares the similar molecular mechanism as other neurodegenerative disorders such as Alzheimer's and Parkinson's disease in which mutant protein form due to defective/ mutant DNA, these proteins accumulate inside neuronal cells and cause Neurodegeneration. The disorders affect mainly cerebellar regions, cerebellar connections, and its associated pathways in addition to other brain regions. The general characteristics of SCAs are cognitive impairment, depression, and motor deficits. The most prominent symptom observed in SCAs patients is ataxia with other varying non-ataxia symptoms in the majority of phenotypes. The modern classification strategies of the disorder is based upon expanding genotype. Due to overlap in clinical manifestation of many SCAs types, Genetic test, and various screening tools, for instance, Magnetic Resonance Imaging (MRI), Positron Emission Tomography (PET) and Electromyography used to confirm the accumulation of mutant protein and aberrant neuronal mechanism responsible for the causation of particular phenotype. Nucleotides repeat expansion which is the basis of genetic disorder of SCAs can be determine by sequencing procedure. Similarly, techniques such as polymerase chain reaction (PCR) and gel electrophoresis with other molecular techniques and appliances used for the screening of patients in large number. The aim of this study was to explore the methods available for the screening of SCAs which form the basis of differential genetic diagnosis and list all the distinguishable clinical features and treatments available for SCAs.
\end{abstract}

Keywords: Ataxia, Neuronal disorder, Spinocerebellar, Movement disorder, Neurodegenerative disease.

\section{Introduction}

The term ataxia refers to the loss of body balance and coordination while performing movements ${ }^{1}$. Conventionally, the autosomal dominant inherited ataxia is called spinocerebellar ataxia (SCA) ${ }^{2}$. Typical clinical features of SCAs are gait ataxia, appendicular ataxia followed by dysarthria, ocular difficulties in moving surrounding like saccadic eye movement, diplopia. Noncerebellar eye movement abnormalities are ocular "stare", blepharospasm, gaze palsies, ptosis and slowed saccades. Intention tremor on the finger to nose testing, dysmetria, widened stance and difficulty with gait, mainly when turning and rebound phenomena are characteristic cerebellar abnormalities ${ }^{3}$.

The age of onset of disease is variable usually it is adult onset $^{4}$. The worldwide prevalence of Autosomal dominant spinocerebellar ataxia is found to be 1 to 5 cases per 100,000 population $^{5,6}$. Among all SCAs, SCA 3 is most common type which also known as Machado-Joseph disease (MJD) followed by SCA 1, 2, 6 and $7^{7-21}$. The site of mutation in different regions of the genome responsible for the numerous SCA types, several of the gene associated with this mutant site have already identified. Based upon the types of mutations, SCAs are categorized in 3 main group, group 1st is refers to SCAs with expanded CAG/polyQ ataxia, nonprotein coding repeat expansion ataxia comes under 2nd group and SCAs with conventional mutations (deletion, insertion, duplication, frameshift, and missense) kept in group 3rd. In SCAs most coalescing feature is a pattern of neurodegeneration, often clinician associate the disorder with clinical features which reflects the region of brain damage. ${ }^{3}$ A growing body of evidence suggest the similar molecular mechanism behind the disease as other neurodegenerative diseases. Although based upon the types of mutation SCAs kept in 3 group but on the basis of genetic mechanism of disease, SCAs falls into four categories. Here it is noteworthy that the above 4 categories is for those SCAs in which the responsible gene has been identified already. The first category is SCAs with exonic triplet CAG repeats, for instance, SCA 1, 2, 3, 6, 7, 17, dentatorubropallidoluysian atrophy (DRPLA), and SCA 8 (partly), these codes for long, abnormal polyglutamine tracts within translated protein and results in a gain of toxic functions to these translated proteins. The second category is of SCAs with intronic or non-coding repeat expansion SCA 10, 12, 31, 36 and SCA 8(partly), some of these may involve in RNA-mediated toxicity. SCA 5, 11, 13, 14, 19/22, 23, 26, 27, 28, 29, and 35 with point mutations (including small insertions or deletions) may involve in a gain of novel function, haploinsufficiency or even dominant negative effect classified in category three of classification of the genetic mechanism. In last category the 4th one, SCAs with large duplications or deletions as SCA 15 and 20 have kept, they may result in gene dosage mechanisms i.e. under or over translation of the relevant protein products. $^{2}$

\section{Historical Perspective}

The earliest practice of designating a disease with the term ataxia originate in the middle of the 19th century when Tabes dorsalis is named as Locomotor ataxia (a clinical term) by the French neurologist Duchenne de Boulogne. Autosomal dominant hereditary ataxia is referred as SCA, SCAs have assigned a different number based on its order of discovery. The term spinocerebellar ataxia first used in 1950 was based on the model of Friedreich ataxia. In the year, 1993 discovery of unstable CAG trinucleotide repeat expansion in SCA 1 disorder opens the way for the identification of mutations behind other autosomal dominant inherited SCAs.

\section{Volume 5 Issue 12, December 2016}




\section{International Journal of Science and Research (IJSR) \\ ISSN (Online): 2319-7064 \\ Index Copernicus Value (2015): 78.96 | Impact Factor (2015): 6.391}

The method used previously for the identification and analysis of disease was linkage analysis. Gene discovery is the most recent method of identification of disorder. In the 20th century classification and neuropathological approaches to ataxia was based on the pivotal work of Greenfield and Holmes. The classification categories were based on the neuropathological characters such as spinocerebellar degeneration, or cerebellar cortical atrophy, olivopontocerebellar atrophy. However, this classification was not proper and the general consensus acceptance never reached. A new classification done by the professor Anita Harding in the beginning of 80s of the 20th century change the situation. SCAs were classified into four different types by Harding based on the specific characteristics, the four types are given as follows: The characteristics associated with Type 1 were cerebellar ataxia with optic atrophy, dementia, ophthalmoplegia, extrapyramidal signs, and amyotrophy. Disease symptoms ophthalmoplegia and extrapyramidal signs with retinal degeneration were kept in Type 2. The third category of classification (Type 3) was implicated with pure cerebellar ataxia. Type 4 was defined with the symptoms myoclonia and deafness in addition to cerebellar ataxia. Figure-1 exhibit most important events of ataxia on the historical timeline. Table- 1 articulate the description of these important major historical proceedings on ataxia. ${ }^{22,23}$

Figure 1: Most important events of ataxia on historical timeline

Table 1: Most important Historical occurrences of ataxia

\begin{tabular}{|c|c|}
\hline Period & Historical occurrence \\
\hline \begin{tabular}{|l}
$\begin{array}{l}\text { Mid of the } 19^{\text {th }} \\
\text { century }\end{array}$ \\
\end{tabular} & $\begin{array}{c}\text { Term ataxia used to designate a disease (Tabes } \\
\text { dorsalis termed as locomotor ataxia) }\end{array}$ \\
\hline 1863 & $\begin{array}{c}\text { Friedreich describe in details the first ataxia } \\
\text { disorder }\end{array}$ \\
\hline $20^{\text {th }}$ century & $\begin{array}{c}\text { Neuropathological approach to ataxia and } \\
\text { Neuropathological category based classification } \\
\text { of ataxia established }\end{array}$ \\
\hline 1950 & $\begin{array}{l}\text { A historical term first used in 1950s based on } \\
\text { Friedreich ataxia as a model }\end{array}$ \\
\hline $\begin{array}{c}\text { Eighties of } 20^{\text {th }} \\
\text { century }\end{array}$ & \begin{tabular}{|c|} 
New classification of SCA by Harding based on \\
genetic and clinical criteria
\end{tabular} \\
\hline 1993 & $\begin{array}{l}\text { Identification of mutation causing dominantly } \\
\text { inherited SCAs started, unstable expansion of a } \\
\text { translated CAG repeats cause SCA-1, identified }\end{array}$ \\
\hline $\begin{array}{l}\text { Nineties of } \\
\text { 20th century }\end{array}$ & $\begin{array}{l}\text { Clinical research establish that the SCA-1, SCA- } \\
\text { 2, SCA-3 Patients demonstrate additional } \\
\text { symptoms in addition to ataxia while SCA-6 is } \\
\text { an almost pure cerebellar ataxia }\end{array}$ \\
\hline
\end{tabular}

\section{Symptoms and Visible Characteristics}

SCAs are a group of complex disease which is heterogeneous in genotypic as well as phenotypic sense. The phenotypic heterogeneity implies that the different phenotype is determined by the same genotype, genotypic heterogeneity defined as the presence of the same phenotype although the genotypes are different. ${ }^{24}$ The modern or new classification of ataxia is based on the order of discovery of locus of mutation. The number of genes have determined which implicated with these discovered locus although few of them yet to be determined, the most common features related to disease are uncoordinated movement, eye and speech impairments, cognitive decline, neuropathy, and spasticity. ${ }^{4,} 25$ The current status of genetic testing is limited and cannot offer testing for all types of ataxia. The initial decision of genetic testing for a particular type of ataxia based on the clinical features that differentiate among many types, patient disease history and family disease history. ${ }^{26}$ Table-2 summarizes the particular gene/locus, mutation, average onset time, average disease duration and clinical

\section{Volume 5 Issue 12, December 2016}




\section{International Journal of Science and Research (IJSR) ISSN (Online): 2319-7064 \\ Index Copernicus Value (2015): 78.96 | Impact Factor (2015): 6.391}

features associated with SCAs types. The clinical symptoms ataxia symptoms associated with different SCAs.

is also included non-ataxia symptoms in addition to the

Table 2: SCA types, their genes, mutations, average onset, average duration and distinguished clinical features

\begin{tabular}{|c|c|c|c|c|c|}
\hline SCAs Types & Gene/ Locus & Mutation & $\begin{array}{l}\text { Ranges in Years } \\
\text { (Average onset) }\end{array}$ & $\begin{array}{l}\text { Ranges in Years } \\
\text { (Average } \\
\text { durations) }\end{array}$ & Distinguish Clinical Features \\
\hline \multirow[t]{2}{*}{ SCA 1} & \multirow[t]{2}{*}{ ATXN1 } & \multirow[t]{2}{*}{ CAG repeat } & \multirow{2}{*}{$\begin{array}{c}<10 \text { to }>60 \text { (3rd-4th } \\
\text { decade) }\end{array}$} & \multirow[t]{2}{*}{$10-28(15)$} & Pyramidal signs, \\
\hline & & & & & Peripheral neuropathy, \\
\hline SCA 2 & ATXN2 & CAG repeat & $\begin{array}{c}<10 \text { to }>60 \text { (3rd-4th } \\
\text { decade) }\end{array}$ & $1-30(10)$ & $\begin{array}{c}\text { Slow saccades, Peripheral neuropathy, Decreased } \\
\text { DTRs, Dementia }\end{array}$ \\
\hline SCA 3 & ATXN3 & CAG repeat & 10-70 (4th decade) & $1-20(10)$ & $\begin{array}{l}\text { Pyramidal sign, Amyotrophy fasciculations, } \\
\text { sensory loss, Lid retraction, nystagmus, and } \\
\text { decreased saccade velocity, }\end{array}$ \\
\hline SCA 4 & $16 q 22.1$ & Unidentified & $\begin{array}{l}19-72\left(4 \text { th- } 7^{\text {th }}\right. \\
\text { decade) }\end{array}$ & (Decades) & Sensory axonal neuropathy, Deafness \\
\hline SCA 5 & SPTBN2 & $\begin{array}{c}\text { Missense, in frame } \\
\text { deletion }\end{array}$ & $\begin{array}{l}10-68\left(3 r d-4^{\text {th }}\right. \\
\text { decade) }\end{array}$ & (>25 years) & $\begin{array}{c}\text { Pure cerebellar ataxia (late onset), Pyramidal sign } \\
\text { (early onset) }\end{array}$ \\
\hline SCA 6 & CACNA1A & CAG repeat & $\begin{array}{l}19-71\left(5 \text { th- } 6^{\text {th }}\right. \\
\text { decade) }\end{array}$ & (>25 years) & Pure cerebellar ataxia late onset \\
\hline SCA 7 & ATXN7 & CAG repeat & $\begin{array}{l}0.5-60 \text { (3rd-4th } \\
\text { decade) }\end{array}$ & $\begin{array}{c}\text { Early onset } \\
\text { correlate with } \\
\text { shorter duration, } \\
1-45(20)\end{array}$ & Pigmentary macular degeneration \\
\hline SCA 8 & ATXN8 & CTG \& CAG repeat & $1-65$ ( $4^{\text {th }}$ decade $)$ & $\begin{array}{l}\text { (Normal life } \\
\text { span) }\end{array}$ & $\begin{array}{c}\text { Pyramidal sign, Sometimes brisk DTRs, decreased } \\
\text { vibration sense, Rarely, cognitive impairment, } \\
\text { Slowly progressive }\end{array}$ \\
\hline SCA 9 & Not Assigned & & & & \\
\hline SCA 10 & ATXN10 & \begin{tabular}{|c|} 
ATTCT Penta \\
nucleotide expansion
\end{tabular} & 12-48 (4th decade) & (9 years) & es \\
\hline SCA 11 & TTBK2 & Frameshift & 15-70 (age 30 years) & $\begin{array}{l}\text { (Normal life } \\
\text { span) }\end{array}$ & bellar ataxia \\
\hline SCA 12 & $P P P 2 R 2 B$ & CAG repeat & 8-62 (4th decade) & & $\begin{array}{c}\text { Upper extremity tremor, Slowly progressive } \\
\text { ataxia, Subtle parkinsonism possible, Action tremor } \\
\text { in the 30s, Hyperreflexia, Cognitive/psychiatric } \\
\text { disorders including dementia }\end{array}$ \\
\hline SCA 13 & KCNC3 & Missense & $\begin{array}{l}\text { Adulthood or } \\
\text { childhood }\end{array}$ & Unknown & Intellectual disability, Short stature \\
\hline SCA 14 & PRKCG & Miss & $\begin{array}{l}\text { 3-70 (3rd-4th } \\
\text { decade) }\end{array}$ & $1-30($ & Pure cerebellar ataxia, Early axial myoclonus \\
\hline SCA 15 & ITPR1 & Deletion \& Missense & 7-66 (4th decade) & ades) & Pure cerebellar ataxia \\
\hline SCA 16 & ITPR1 & Deletion \& Missense & 20-66 (age 39 years) & (1-40 years) & Pure cerebellar ataxia, Head tremor \\
\hline SCA 17 & TBP & CAG repeat & 3-55 (4th decade) & ( $>8$ years $)$ & $\begin{array}{l}\text { Chorea, dystonia, myoclonus, epilepsy, Mental } \\
\text { deterioration }\end{array}$ \\
\hline SCA 18 & 7q22-q32 & Unidentified & 12-25 (adolescence) & (Decades) & $\begin{array}{c}\text { Posterior column loss, Decreased tendon reflexes, } \\
\text { Dysarthria, Nystagmus, Ataxia with early } \\
\text { sensory/motor neuropathy }\end{array}$ \\
\hline \begin{tabular}{|l|} 
SCA $19 / 22$ \\
\end{tabular} & KCND3 & Deletion \& Missense & 10-51 (4th decade) & (Decades) & $\begin{array}{c}\text { Pure cerebellar ataxia, slowly progressive, } \\
\text { Myoclonus, Hyperreflexia, rare cognitive } \\
\text { impairment }\end{array}$ \\
\hline SCA 20 & $\begin{array}{l}11 \mathrm{q} 12.2- \\
11 \mathrm{q} 12.3\end{array}$ & Duplication & 19-64 (5th decade) & (Decades) & $\begin{array}{l}\text { Spasmodic dysphonia or Spasmodic coughing, } \\
\text { Bradykinesia, Hyperreflexia, Early dysarthria }\end{array}$ \\
\hline SCA 21 & TMEM240 & Missense \&Nonsense & & ades) & Mild to severe early-onset cognitive impairment \\
\hline SCA 23 & $P D Y N$ & Missense & (5th-6th) & (>10 years) & $\begin{array}{c}\text { Late onset, Abnormal eye movements, Dysarthria, } \\
\text { Reduced vibration and position sense }\end{array}$ \\
\hline SCA 25 & SCA25 & Unidentified & $1.5-39$ & Unknown & Sensory neuropathy \\
\hline SCA 26 & EEF2 & Missense & $26-60$ & Unknown & Irregular visual pursuits, Dysarthria \\
\hline SCA 27 & FGF14 & $\begin{array}{r}\text { Missense \& } \\
\text { Frameshift }\end{array}$ & 7-20 (age 11 years) & (Decades) & $\begin{array}{c}\text { Orofacial dyskinesia, Cognitive deficits, Early-onset } \\
\text { tremor }\end{array}$ \\
\hline SCA 28 & AFG3L2 & Missense & $\begin{array}{l}12-36 \text { (age } 19.5 \\
\text { years) }\end{array}$ & (Decades) & $\begin{array}{l}\text { Early onset, Increased tendon reflexes, Ptosis, } \\
\text { Ophthalmoparesis, Nystagmus }\end{array}$ \\
\hline SCA 29 & ITPR1 & Missense & Early Childhood & (Lifelong) & Congenital, Learning deficits \\
\hline SCA 30 & $4 q 34.3-q 35.1$ & Unide & $45-76$ & (Lifelong) & Hyperreflexia \\
\hline SCA 31 & BEAN1 & $\begin{array}{c}\text { TGGAA Penta } \\
\text { nucleotide repeat }\end{array}$ & $\begin{array}{l}61.2 \text { (3rd-4th } \\
\text { decade) }\end{array}$ & Unknown & Pure cerebellar ataxia late onset, usually $>50$ years \\
\hline SCA 34 & ELOVL4 & Missense & $\begin{array}{c}\text { Early Childhood } \\
\text { (4th or 5th decade) }\end{array}$ & Unknown & Skin changes disappear in adulthood \\
\hline SCA 35 & TGM6 & Missense \&deletion & Teenage to late & Unknown & Pyramidal sign \\
\hline
\end{tabular}

\section{Volume 5 Issue 12, December 2016}


International Journal of Science and Research (IJSR)

ISSN (Online): 2319-7064

Index Copernicus Value (2015): 78.96 | Impact Factor (2015): 6.391

\begin{tabular}{|c|c|c|c|c|c|}
\hline SCA 36 & NOP56 & $\begin{array}{c}\text { GGCCTG } \\
\text { Hexanucleotide } \\
\text { Repeat }\end{array}$ & Adulthood & Unknown & $\begin{array}{c}\text { Lower motor neuron involvement, Hyperreflexia, } \\
\text { Tongue atrophy, Muscle fasiculations }\end{array}$ \\
\hline SCA 37 & 1p32 & Unidentified & Adulthood & Unknown & Abnormal vertical eye movements \\
\hline SCA 38 & ELOVL5 & Missense & Adulthood & Unknown & Axonal neuropathy, Adult onset \\
\hline SCA 40 & CCDC88C & Missense & Adulthood & Unknown & Brisk reflexes, Spasticity, Adult onset \\
\hline DRPLA & ATN1 & CAG repeat & 20 & Unknown & Myoclonic epilepsy, Dementia, Seizures, Chorea \\
\hline SCA 42 & CACNA1G & Missense & Highly Variable & Unknown & Saccadic pursuit, Mild pyramidal signs \\
\hline
\end{tabular}

DTR, deep tendon reflex

Symptoms in Bold typeface represent unique or characteristic feature of the particular SCA type

\section{Methods for screening of SCAs}

Numerous methods of identification of different types of SCAs applied in hospitals and research laboratory for screening, Figure-2 display the available methods for primary/ initial screening of different types of SCAs. Theses screening methods helpful in the construction of Algorithm for differential genetic diagnosis of SCAs.

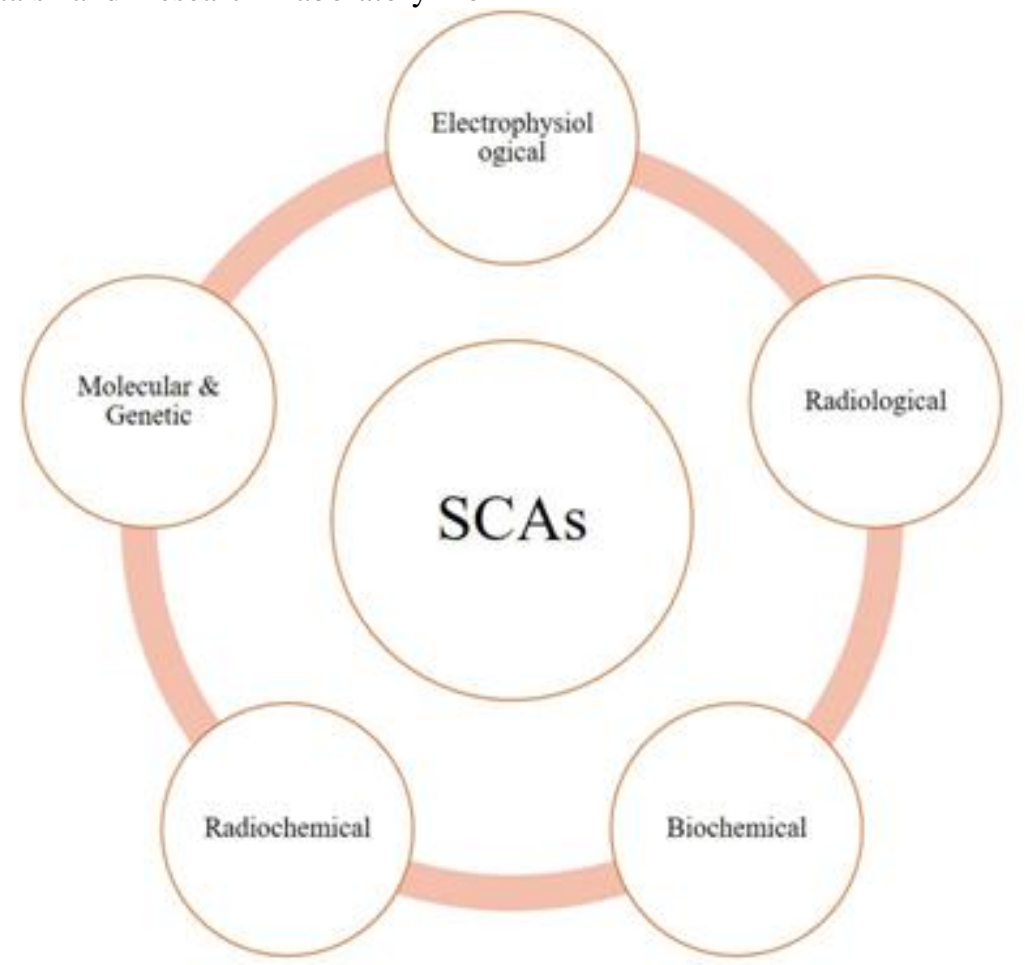

Figure-2 Screening methods helpful in the construction of differential genetic testing algorithm for SCAs

The detail descriptions of screening methods of SCAs are as follows:

\subsection{Electrophysiological}

The basis of this method is an electrophysiological measurement of masseter reflex. The initial study was done on the patients of SCA type 2 and 3 by Antonio Garcia et al., the device used for the study was electromyography (EMG) system (Medelec-Synergy EMG/PE; Cardinal Health, UK). Masseter reflex measurement is a reliable test that discriminates between the SCA type 2 and 3, although this method was used for primary screening purpose. ${ }^{27}$

\subsection{Radiological}

A study carried by Yoshio Murata et al. found the certain characteristics feature of the brain of MJD patients in MRI study. The MRI study demonstrates the atrophy of temporal and frontal lobe in addition to Globus pallidus, abnormality in afferent and efferent cerebellar tracts also reported. These features may helpful in finding difference between sporadic olivopontocerebellar atrophy (sOPCA) and MJD. ${ }^{28}$ Another published work of Yoshio Murata et al. signify the distinguishable feature of SCA 6 from other SCAs forms, in an MRI study of the brain. The MRI study shows the affected cerebellar region and its afferent and efferent system. $^{29}$ MRI is the steadfast method to find the affected brain regions in SCAs patient and other neurodegenerative disorder but it is not a confirmatory test for SCAs types, due to several overlap in clinical characteristics.

\subsection{Biochemical}

A study done by Marcelle R. Morrison and Roger N. Rosenberg on the brain of Machado-Joseph disease patients led the finding that there were an elevation in steady state level of many proteins such as glial fibrillary acidic protein complex, J protein complex, and L protein complex in the cerebellar and cortex region of brain in comparison to the control brain protein analysis. ${ }^{30}$

\section{Volume 5 Issue 12, December 2016 www.ijsr.net}




\section{International Journal of Science and Research (IJSR) \\ ISSN (Online): 2319-7064}

Index Copernicus Value (2015): 78.96 | Impact Factor (2015): 6.391

\subsection{Radiochemical}

An comparative analysis of dopamine transporter and regional cerebral glucose metabolism (rCMRglu) by using [11C]d-threo-methylphenydate ([11C]dMP) and [18F]fluorodeoxyglucose ([18F]FDG) respectively and Positron emission tomography (PET) screening carried by Ullrich Wüllner et al., in patients with SCA 1, 2, 3 and 6 in comparison to Parkinson disease (PD) patients and healthy controls. Their findings reflect the specific pattern of neuronal susceptibility met in each polyglutamine disorder. The specific pathological features observed in patients with SCA 1, SCA 2, SCA 3 and SCA 6 provide a stepping stone for the identification of disorder among several pathotypes. They observed no significant change in the striatal [11C]dMP binding potential (BPdMP) but reduce rCMRglu in the cerebellum and brain stem of SCA 1 patients. . In SCA 2 patient's striatal BPdMP was evidently reduced, putamen and caudate nucleus region showed the 57 and $55 \%$ of BPdMP reduction respectively. An increment in the rCMRglu was noted in the temporal cortical region of interest (ROI) analysis. The dopamine terminal (DAT) loss was throughout striatum and similar to PD with a more severely affected putamen. Particularly in the case of SCA 2 mutation, the dopaminergic system was sensitive. Pathological features of SCA 3 demonstrated the marked reduction of striatal BPdMP. The same degree of reduction of BPdMP in the putamen (29\%) and caudate (20\%) were observed. Brainstem, Thalamus and putamen region of brain displayed, the reduce level of rCMRglu, the area of decreased metabolism extended from cerebellar midline structures to adjacent pons and midbrain. An increased metabolism was observed in the superior and middle temporal gyri. The loss of DAT observed in SCA 3 patients but it was less severe in comparison to patients with SCA 2. The loss of dopaminergic cells and global synaptic impairment might contribute to the alterations of DATs in SCA 3 patients. Reduced rCMRglu level was observed in the putamen region of patients with SCA 6. Differentiated brain regions with the increase and decrease metabolic activity were observed in temporal gyri (superior, middle) and Cerebellum respectively in patients with SCA $6 .{ }^{31}$ A study done by Bing-wen Soong and Ren-shyan Liu in asymptomatic gene carriers of MJD demonstrate a regional decrease in brain glucose metabolism. They used positron emission tomography (PET) with [18F]-2-fluoro-2-deoxy-Dglucose (FDG) to record the metabolic changes in the asymptomatic carrier. $^{32}$

\subsection{Molecular and Genetic}

Molecular and genetic testing techniques depend on the diverse types of mutation implicated in different SCAs types. The most common type of mutation is trinucleotide (CAG) repeats found in coding regions of genes in SCA 1, 2, 3, 6, 7, 17 and DRPLA. Bidirectional transcribed CTG and CAG repeats in 3'UTR ATXN8OS region as well as ORF ATXN8 region found in SCA 8. The nontranslated mutation found in SCA 10, SCA 12 and SCA 31, pentanucleotide repeat ATTCT and TGGAA found in the intronic region of SCA 10 and SCA31 respectively, CAG repeats present in 5'UTR of SCA 12. Hexanucleotide repeats GGCCTG found in the intronic region of genes in SCA 36. The conventional mutations (missense, deletion, duplication and frameshift) has reported in SCA type 5, 11, 13, 14, 15, 16, 20,21,23,26, 27, 28, 29,34, 35, 38, 40 and 42 and DRPLA. ${ }^{23,33-50}$ Table-2 demonstrate the particular mutation and associated SCAs types. The most reliable and popular method of screening of spinocerebellar ataxia is Genetic diagnosis which relies upon Genetic material DNA and molecular techniques. The molecular genetic screening method used in different parts of the world in various races of Human population. In most of the SCAs where the mutation is due to nucleotides repeats, PCR screening technique is used to amplify the mutated region of the genomic fragment, analysis of amplified region is done with gel electrophoresis or automated sequencer. ${ }^{51-56}$

The other molecular techniques include repeat expansion detection (RED) method, Linkage analysis, Whole-Exome sequencing, Whole genome sequencing and whole mitochondrial sequencing. Kerstin Lindblad et al. used the RED method to detect CAG repeats in SCA 7 patients and in their family, in the RED method they used thermostable DNA ligase to detect repeats directly from DNA. ${ }^{57}$ Lourdes Martorell et al. detected CAG/CTG expansion in SCA 1 and MJD patients by using the RED method. ${ }^{58}$ The detection of CAG repeat expansion in MJD patients by RED method demonstrated in another publication by Kerstin Lindblad et al. ${ }^{59}$ A published work of Kokoro Ozaki et al. and Je'ro`me Delplanque et al. demonstrate the use of linkage analysis in determination of mutation in SCA 34 and SCA 21 respectively. In the Genome-wide linkage analysis, they used SNP array chip for mutation detection. Most of the SCAs which cannot be identified by molecular techniques such as PCR, RED, and linkage analysis method can identify by Whole exome sequencing, whole genome sequencing or whole mitochondrial sequencing. Sequencing technique most preferably used for the identification of Conventional mutations linked SCAs. ${ }^{23,36,37}$ Numerous combination of molecular techniques and appliances which also include variants of PCR are used for the genetic screening of SCAs. ${ }^{60-72}$

\section{Algorithm for the differential genetic diagnosis of SCAs}

Differential genetic diagnosis of SCAs depend upon the number of factors, to proceed for the genetic diagnosis it is very much important that the details of clinical history, family history and outcomes of all neurological examination must be known. The first step is to rule out all the acquired (non-genetic) cause of ataxia such as vitamin deficiencies, multiple sclerosis, vascular disease, primary or metastatic tumors, alcoholism, or paraneoplastic diseases associated with occult carcinoma of the breast, ovary, or lung and then proceed for the genetic testing. Figure-3 describe the steps involve in differential genetic diagnosis of SCAs. ${ }^{23,73,74}$ 


\title{
International Journal of Science and Research (IJSR) \\ ISSN (Online): 2319-7064
}

Index Copernicus Value (2015): 78.96 | Impact Factor (2015): 6.391

\begin{abstract}
Details of Clinical History and Symptoms, Family history and Neurological examination including Electrophysiological, Radiological, Biochemical and

Radiochemical analysis
\end{abstract}

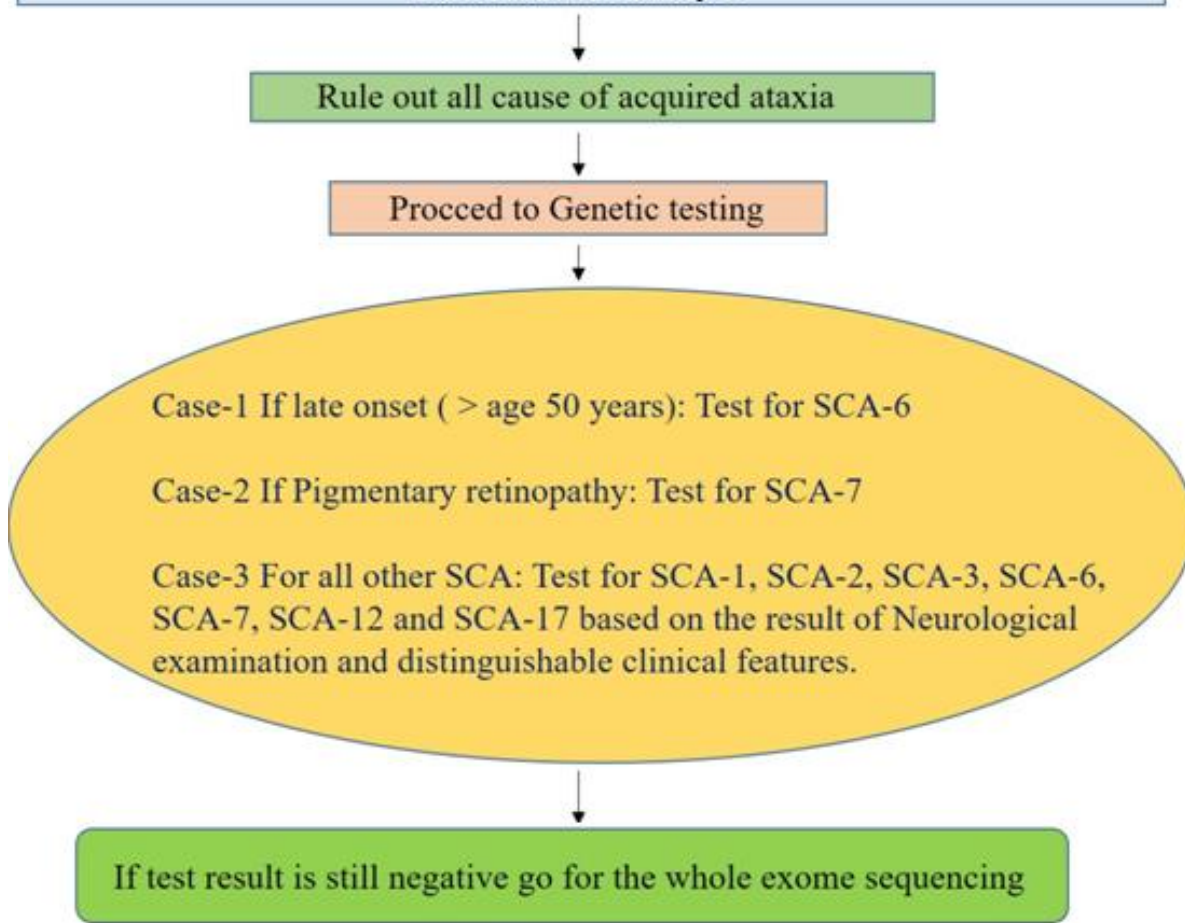

Figure 3: Algorithm for differential genetic diagnosis of SCAs

\section{Approaches for the treatment of SCAs}

In most of hereditary ataxia, only supportive treatment is possible these includes centrally acting drugs such as 5hydroxytryptophan, buspirone and physostigmine and thyrotropin-releasing hormone and D-cycloserine. ${ }^{22}$ To develop the definite and possible cure for ataxia patients many approach and different experimentation have been carried out and ongoing. A study done by Song Tan et al., in SCA 3 patients determined the potential of Nerve growth factor for the treatment of SCA 3. A clinical assessment of effect of N-acetylcysteine on 18 patients of Spinocerebellar disease by Dr. Roswell Eldridge demonstrate a marked improvement in degrees of ataxia, dysarthria and oculomotor disturbance from disease condition. Jia-Li Jin et al., experimentation on 16 SCAs patients (Genetically diagnosed and confirmed) including SCA-1, SCA 2 and SCA 3 establish the improvement in motor and balancing ability after receiving intrathecal and intravenous infusion of umbilical cord Mesenchymal Stem cells (MSCs). The laboratory examinations demonstrated that the umbilical cord-MSC therapy was safe. In addition to clinical study of human subjects, In vivo and In vitro studies on Cell lines and Animal Models determine the possibilities of cure in Human subjects. A study by Vladimir F. Lazarev et al., in Cell and Fly model of spinocerebellar ataxia 3 prove the Neuroprotective role of glyceraldehyde-3-phosphate dehydrogenase (GAPDH) binding drugs such as Deprenyl (DEP) and 2-amino-4,7 dimethyl benzothiazole (PGL). GAPDH form the complex with protein with long polyglutamine repeats. Additional approaches which could be possible for the treatment of ataxia enlisted by David D.
Bushart et al., in his review paper, These are (1) RNA interference and Antisense Oligonucleotide-based strategies (2) Heat Shock Protein (Hsp) 70 and Hsp 27 activation (3) Use of Histone deacetylase (HDAC) Inhibitor Expression of Calcium binding protein and Inhibitor of Intracellular Calcium release store (5) Dantrolene and Glutamate transport activator (6) Potassium channel modulator and Calcium-activated potassium channel activators. The RNA interference or Antisense oligonucleotide strategies have been used in mouse model of SCA 1, SCA 3 and SCA 7 for silencing of specific mutant allele which leads to the improvement in condition from disease state. It may have relevance for the treatment of SCAs in human subjects. Lymphoblastoid cells derived from SCA 7 patient show reduced expression of Hsp70 and Hsp27, activation of these two proteins may have neuroprotective benefit. In SCA 3 mouse model H3 and H4 histone found to be hypo acetylated it suggest the presence of HDAC over activity, use of HDAC inhibitor Sodium butyrate in SCA 3 mouse model improve Histone acetylation and increase the expression of gene which were suppressed earlier in cerebellum region. HDAC inhibitors may have therapeutic promise for the treatment of some forms of SCA, particularly those which display repressed gene transcription condition. Drug-mediated treatments which increase the glutamate uptake, increase expression of calcium binding proteins, or inhibit intracellular calcium release store and modulate potassium channel might be promising candidates for treating neuronal dysfunction and synaptic physiology across different cause of SCAs. Table-3 summarize the possible available and continuing treatment methods for SCAs with brief description. ${ }^{75-81}$ 


\section{International Journal of Science and Research (IJSR) \\ ISSN (Online): 2319-7064}

Index Copernicus Value (2015): 78.96 | Impact Factor (2015): 6.391

Table 3: Possible treatment types of SCA and their descriptions

\begin{tabular}{|c|c|}
\hline Treatment Types & Description \\
\hline $\begin{array}{c}\text { Deprenyl (DEP) and 2-amino-4,7- } \\
\text { dimethylbenzothiazole (PGL) }\end{array}$ & $\begin{array}{c}\text { Glyceraldehyde-3-phosphate dehydrogenase (GAPDH) binding drugs have neuro- } \\
\text { protective activity in cell and fly (Drosophila) model of SCA-3 }\end{array}$ \\
\hline $\begin{array}{c}\text { Human Umbilical derived Mesenchymal Stem cells } \\
\text { (MSCs) }\end{array}$ & $\begin{array}{c}\text { Intrathecal and Intravenous injection of Umbilical MSCs to Human ataxia patients } \\
\text { (SCA-1, SCA-2 and SCA-3) improve the motor and balancing ability. }\end{array}$ \\
\hline $\begin{array}{c}\text { Medication in Spinocerebellar disease patients demonstrate improvement in } \\
\text { degrees of ataxia, dysarthria, and oculomotor disturbance from disease condition. }\end{array}$ \\
\hline $\begin{array}{c}\text { RNA interference based and Antisense } \\
\text { oligonucleotide based strategies }\end{array}$ & $\begin{array}{c}\text { Silence specific alleles may have relevance for the treatment of polyglutamine in } \\
\text { SCAs. }\end{array}$ \\
\hline $\begin{array}{c}\text { Heat shock protein (Hsp) 70 and Hsp 27 activation } \\
\text { Histone deacetylase (HDAC) inhibitor }\end{array}$ & $\begin{array}{c}\text { Hsp70 and Hsp27activators may promote clearance and degradation of } \\
\text { polyglutamine proteins, have neuroprotective benefits in SCAs }\end{array}$ \\
\hline $\begin{array}{c}\text { Molecules increase expression of calcium binding } \\
\text { protein or inhibit intracellular calcium release store }\end{array}$ & $\begin{array}{c}\text { It may improve neuronal health and limit calcium-mediated neuronal toxicity } \\
\text { gene transcription. }\end{array}$ \\
\hline Dantrolene and glutamate transport activator \\
\hline $\begin{array}{c}\text { Small-conductance calcium-activated potassium } \\
\text { (SK) channel activators }\end{array}$ & Improve synaptic physiology \\
\hline
\end{tabular}

\section{Conclusion}

This review illustrates the clinical manifestation and available diagnostic methods and treatment of neurodegenerative disorder SCAs. It is very necessary for the individual patients and their family to come to an appropriate diagnosis to confirm the disorder and affected regions of the body. The gold standard test for SCAs is a Molecular and Genetic diagnosis, Although Physiological, Radiological, and Radiochemical methods are not confirmatory tests but it is helpful in the determination of affected brain region and extent of damage occurs to the brain and construction of algorithm for the differential genetic diagnosis of SCAs. These test may also confirm the anticipated consequence to the body as the Nervous system is a master controller of organs and organs associated functions. This review also summarize the outcome of various experimental approaches for the treatment of SCAs.

\section{References}

[1] Orr HT. "Cell biology of spinocerebellar ataxia," J Cell Biol., 197(2), pp. 167-177, 2012.

[2] Storey E. "Genetic cerebellar ataxias," Semin Neurol., 34(3), pp. 280-292, 2014.

[3] Paulson HL. "The spinocerebellar ataxias," J Neuroophthalmol., 29(3), pp. 227-237, 2009.

[4] Jayadev S, Bird TD. "Hereditary ataxias: overview," Genet Med., 15(9), pp. 673-683, 2013.

[5] van de Warrenburg BP, Sinke RJ, VerschuurenBemelmans CC, Scheffer H, Brunt ER, Ippel PF, MaatKievit JA, Dooijes D, Notermans NC, Lindhout D, Knoers NV, Kremer HP. "Spinocerebellar ataxias in the Netherlands: prevalence and age at onset variance analysis," Neurology., 58, pp. 702-708, 2002.

[6] Ruano L, Melo C, Silva MC, Coutinho P. "The global epidemiology of hereditary ataxia and spastic paraplegia: a systematic review of prevalence studies," Neuroepidemiology., 42, pp. 174-183, 2014.

[7] Schöls L, Amoiridis G, Buttner T, Przuntek H, Epplen JT, Riess O. "Autosomal dominant cerebellar ataxia: phenotypic differences in genetically defined subtypes?,” Ann Neurol., 42, pp. 924-932, 1997.
[8] Moseley ML, Benzow KA, Schut LJ, Bird TD, Gomez CM, Barkhaus PE, Blindauer KA, Labuda M, Pandolfo M, Koob MD, Ranum LP. "Incidence of dominant spinocerebellar and Friedreich triplet repeats among 361 ataxia families," Neurology., 51, pp. 1666-1671, 1998.

[9] Saleem Q, Choudhry S, Mukerji M, Bashyam L, Padma MV, Chakravarthy A, Maheshwari MC, Jain S, Brahmachari SK. "Molecular analysis of autosomal dominant hereditary ataxias in the Indian population: high frequency of SCA2 and evidence for a common founder mutation," Hum Genet., 106, pp. 179-187, 2000.

[10] Storey E, du Sart D, Shaw JH, Lorentzos P, Kelly L, McKinley Gardner RJ, Forrest SM, Biros I, Nicholson GA. "Frequency of spinocerebellar ataxia types 1, 2, 3, 6, and 7 in Australian patients with spinocerebellar ataxia,”. Am J Med Genet., 95, pp. 351-357, 2000.

[11] Tang B, Liu C, Shen L, Dai H, Pan Q, Jing L, Ouyang S, Xia J. "Frequency of SCA1, SCA2, SCA3/MJD, SCA6, SCA7, and DRPLA CAG trinucleotide repeat expansion in patients with hereditary spinocerebellar ataxia from Chinese kindreds," Arch Neurol., 57, pp. 540-544, 2000.

[12] Maruyama H, Izumi $\mathrm{Y}$, Morino $\mathrm{H}$, Oda $\mathrm{M}$, Toji $\mathrm{H}$, Nakamura S, Kawakami H. "Difference in disease-free survival curve and regional distribution according to subtype of spinocerebellar ataxia: a study of 1,286 Japanese patients,” Am J Med Genet., 114, pp. 578-583, 2002.

[13] Silveira I, Miranda C, Guimaraes L, Moreira MC, Alonso I, Mendonca P, Ferro A, Pinto-Basto J, Coelho J, Ferreirinha F, Poirier J, Parreira E, Vale J, Januario C, Barbot C, Tuna A, Barros J, Koide R, Tsuji S, Holmes SE, Margolis RL, Jardim L, Pandolfo M, Coutinho P, Sequeiros J. "Trinucleotide repeats in 202 families with ataxia: a small expanded (CAG)n allele at the SCA17 locus," Arch Neurol., 59, pp. 623-629, 2002.

[14]van de Warrenburg BP, Sinke RJ, VerschuurenBemelmans CC, Scheffer H, Brunt ER, Ippel PF, MaatKievit JA, Dooijes D, Notermans NC, Lindhout D, Knoers NV, Kremer HP. "Spinocerebellar ataxias in the Netherlands: prevalence and age at onset variance analysis," Neurology., 58, pp. 702-708, 2002.

\section{Volume 5 Issue 12, December 2016}




\section{International Journal of Science and Research (IJSR) \\ ISSN (Online): 2319-7064}

Index Copernicus Value (2015): 78.96 | Impact Factor (2015): 6.391

[15] Dryer SE, Lhuillier L, Cameron JS, Martin-Caraballo M. "Expression of $\mathrm{K}(\mathrm{Ca})$ channels in identified populations of developing vertebrate neurons: role of neurotrophic factors and activity," J Physiol Paris., 97, pp. 49-58, 2003.

[16] Brusco A, Gellera C, Cagnoli C, Saluto A, Castucci A, Michielotto C, Fetoni V, Mariotti C, Migone N, Di Donato S, Taroni F. "Molecular genetics of hereditary spinocerebellar ataxia: mutation analysis of spinocerebellar ataxia genes and CAG/CTG repeat expansion detection in 225 Italian families,". Arch Neurol., 61, pp. 727-733, 2004.

[17] Schöls L, Bauer P, Schmidt T, Schulte T, Riess O. "Autosomal dominant cerebellar ataxias: clinical features, genetics, and pathogenesis," Lancet Neurol. 3, pp. 291-304, 2004.

[18] Shimizu Y, Yoshida K, Okano T, Ohara S, Hashimoto T, Fukushima Y, Ikeda S. "Regional features of autosomal-dominant cerebellar ataxia in Nagano: clinical and molecular genetic analysis of 86 families," J Hum Genet., 49, pp. 610-616, 2004.

[19]Zortea M, Armani M, Pastorello E, Nunez GF, Lombardi S, Tonello S, Rigoni MT, Zuliani L, Mostacciuolo ML, Gellera C, Di Donato S, Trevisan CP. "Prevalence of inherited ataxias in the province of Padua, Italy,”. Neuroepidemiology., 23, pp. 275-280, 2004.

[20] Jiang H, Tang BS, Xu B, Zhao GH, Shen L, Tang JG, Li $\mathrm{QH}, \mathrm{Xia}$ K. "Frequency analysis of autosomal dominant spinocerebellar ataxias in mainland Chinese patients and clinical and molecular characterization of spinocerebellar ataxia type 6," Chin Med J (Engl), 118, pp. 837-843, 2005.

[21] Jiang H, Wang J, Du, J, Duan R, Li J, Tang B. "Progress in treating hereditary ataxia in mainland China. In: Sanders S, Zhang Z, Tang V, eds. Pathways to Cures: Neurodegenerative Diseases in China,”. Washington, DC: Science/AAAS, pp. 32-34, 2013.

[22] Klockgether T, Paulson H. "Milestones in ataxia. Mov Disorder,” 26(6), pp. 1134-1141, 2011.

[23] Bird TD. Hereditary Ataxia Overview. 1998 Oct 28 [Updated 2016 Mar 3]. In: Pagon RA, Adam MP, Ardinger $\mathrm{HH}$, et al., editors. GeneReviews ${ }^{\circledR}$ [Internet]. Seattle (WA): University of Washington, Seattle; 19932016. Available from: http://www.ncbi.nlm.nih.gov/books/NBK1138/

[24] Teive HA. "Spinocerebellar ataxias," Arq Neuropsiquiatr., 67(4), pp. 1133-1142, 2009.

[25] Trott A, Houenou LJ. "Mini-review: spinocerebellar ataxias: an update of SCA genes," Recent Pat DNA Gene Seq., 6(2), pp. 115-121, 2012.

[26] Tan EK, Ashizawa T. "Genetic testing in spinocerebellar ataxias: defining a clinical role,”Arch Neurol., 58(2), pp. 191-195, 2001.

[27] García A, Alvarez S, Infante J, Berciano J. "Masseter reflex in the study of spinocerebellar ataxia type 2 and type 3," Muscle Nerve., 40(4), pp. 640-642, 2009.

[28] Murata Y, Yamaguchi S, Kawakami H, Imon Y, Maruyama H, Sakai T, Kazuta T, Ohtake T, Nishimura M, Saida T, Chiba S, Oh-i T, Nakamura S. "Characteristic magnetic resonance imaging findings in Machado-Joseph disease," Arch Neurol., 55(1), pp. 3337, 1998.
[29] Murata Y, Kawakami H, Yamaguchi S, Nishimura M, Kohriyama T, Ishizaki F, Matsuyama Z, Mimori Y, Nakamura S. "Characteristic magnetic resonance imaging findings in spinocerebellar ataxia 6,". Arch Neurol., 55(10), pp. 1348-1352, 1998.

[30] Morrison MR, Rosenberg RN. "Specific messenger RNA changes in Joseph disease cerebella," Ann Neurol., 14(1), pp. 73-79, 1983.

[31] Wüllner U, Reimold M, Abele M, Bürk K, Minnerop M, Dohmen BM, Machulla HJ, Bares R, Klockgether T. "Dopamine transporter positron emission tomography in spinocerebellar ataxias type 1, 2, 3, and 6," Arch Neurol., 62(8), pp. 1280-1285, 2005.

[32] Soong BW, Liu RS. "Positron emission tomography in asymptomatic gene carriers of Machado-Joseph disease," J Neurol Neurosurg Psychiatry., 64(4), pp. 499-504, 1998.

[33] Marelli C, Cazeneuve C, Brice A, Stevanin G, Dürr A. "Autosomal dominant cerebellar ataxias," Rev Neurol (Paris)., 167(5), pp. 385-400, 2011.

[34] Hara K, Shiga A, Nozaki H, Mitsui J, Takahashi Y, Ishiguro H, Yomono H, Kurisaki H, Goto J, Ikeuchi T, Tsuji S, Nishizawa M, Onodera O. "Total deletion and a missense mutation of ITPR1 in Japanese SCA15 families," Neurology., 71(8), pp. 547-551, 2008.

[35] Duarri A, Jezierska J, Fokkens M, Meijer M, Schelhaas HJ, den Dunnen WF, van Dijk F, VerschuurenBemelmans C, Hageman G, van de Vlies P, Küsters B, van de Warrenburg BP, Kremer B, Wijmenga C, Sinke RJ, Swertz MA, Kampinga HH, Boddeke E, Verbeek DS. "Mutations in potassium channel kcnd3 cause spinocerebellar ataxia type 19," Ann Neurol., 72(6), pp. 870-880, 2012.

[36] Delplanque J, Devos D, Huin V, Genet A, Sand O, Moreau C, Goizet C, Charles P, Anheim M, Monin ML, Buée L, Destée A, Grolez G, Delmaire C, Dujardin K, Dellacherie D, Brice A, Stevanin G, Strubi-Vuillaume I, Dürr A, Sablonnière B. "TMEM240 mutations cause spinocerebellar ataxia 21 with mental retardation and severe cognitive impairment," Brain., 137(Pt 10), pp. 2657-2663, 2014

[37]Lee YC, Durr A, Majczenko K, Huang YH, Liu YC, Lien CC, Tsai PC, Ichikawa Y, Goto J, Monin ML, Li JZ, Chung MY, Mundwiller E, Shakkottai V, Liu TT, Tesson C, Lu YC, Brice A, Tsuji S, Burmeister M, Stevanin G, Soong BW. "Mutations in KCND3 cause spinocerebellar ataxia type 22," Ann Neurol., 72(6), pp. 859-869, 2012.

[38] Bakalkin G, Watanabe H, Jezierska J, Depoorter C, Verschuuren-Bemelmans C, Bazov I, Artemenko KA, Yakovleva T, Dooijes D, Van de Warrenburg BP, Zubarev RA, Kremer B, Knapp PE, Hauser KF, Wijmenga C, Nyberg F, Sinke RJ, Verbeek DS. "Prodynorphin mutations cause the neurodegenerative disorder spinocerebellar ataxia type 23," Am J Hum Genet., 87(5), pp. 593-603, 2010.

[39] Hekman KE, Yu GY, Brown CD, Zhu H, Du X, Gervin K, Undlien DE, Peterson A, Stevanin G, Clark HB, Pulst SM, Bird TD, White KP, Gomez CM. "A conserved eEF2 coding variant in SCA26 leads to loss of translational fidelity and increased susceptibility to proteostatic insult,". Hum Mol Genet., 21(26), pp. 54725483, 2012. 


\section{International Journal of Science and Research (IJSR) \\ ISSN (Online): 2319-7064}

Index Copernicus Value (2015): 78.96 | Impact Factor (2015): 6.391

[40] Huang L, Chardon JW, Carter MT, Friend KL, Dudding TE, Schwartzentruber J, Zou R, Schofield PW, Douglas $\mathrm{S}$, Bulman DE, Boycott KM. "Missense mutations in ITPR1 cause autosomal dominant congenital nonprogressive spinocerebellar ataxia," Orphanet J Rare Dis., 7, pp. 67, 2012.

[41] Cadieux-Dion M, Turcotte-Gauthier M, Noreau A, Martin C, Meloche C, Gravel M, Drouin CA, Rouleau GA, Nguyen DK, Cossette P. "Expanding the clinical phenotype associated with ELOVL4 mutation: study of a large French-Canadian family with autosomal dominant spinocerebellar ataxia and erythrokeratodermia," JAMA Neurol., 71(4), pp. 470475, 2014.

[42] Li M, Pang SY, Song Y, Kung MH, Ho SL, Sham PC. "Whole exome sequencing identifies a novel mutation in the transglutaminase 6 gene for spinocerebellar ataxia in a Chinese family," Clin Genet., 83(3), pp.269-273, 2013.

[43] Wang JL, Yang X, Xia K, Hu ZM, Weng L, Jin X, Jiang H, Zhang P, Shen L, Guo JF, Li N, Li YR, Lei LF, Zhou J, Du J, Zhou YF, Pan Q, Wang J, Wang J, Li RQ, Tang BS. "TGM6 identified as a novel causative gene of spinocerebellar ataxias using exome sequencing," Brain., 133(Pt 12), pp. 3510-3518, 2010.

[44] Guo YC, Lin JJ, Liao YC, Tsai PC, Lee YC, Soong BW. "Spinocerebellar ataxia 35: novel mutations in TGM6 with clinical and genetic characterization," Neurology., 83(17), pp. 1554-1561, 2014.

[45] Kobayashi H, Abe K, Matsuura T, Ikeda Y, Hitomi T, Akechi Y, Habu T, Liu W, Okuda H, Koizumi A. "Expansion of intronic GGCCTG hexanucleotide repeat in NOP56 causes SCA36, a type of spinocerebellar ataxia accompanied by motor neuron involvement," Am J Hum Genet., 89(1), pp. 121-130, 2011.

[46] Serrano-Munuera C, Corral-Juan M, Stevanin G, San Nicolás H, Roig C, Corral J, Campos B, de Jorge L, Morcillo-Suárez C, Navarro A, Forlani S, Durr A, Kulisevsky J, Brice A, Sánchez I, Volpini V, MatillaDueñas A. "New subtype of spinocerebellar ataxia with altered vertical eye movements mapping to chromosome 1p32,” JAMA Neurol., 70(6), pp. 764-771, 2013.

[47] Di Gregorio E, Borroni B, Giorgio E, Lacerenza D, Ferrero M, Lo Buono N, Ragusa N, Mancini C, Gaussen M, Calcia A, Mitro N, Hoxha E, Mura I, Coviello DA, Moon YA, Tesson C, Vaula G, Couarch P, Orsi L, Duregon E, Papotti MG, Deleuze JF, Imbert J, Costanzi C, Padovani A, Giunti P, Maillet-Vioud M, Durr A, Brice A, Tempia F, Funaro A, Boccone L, Caruso D, Stevanin G, Brusco A. "ELOVL5 mutations cause spinocerebellar ataxia 38," Am J Hum Genet., 95(2), pp. 209-217, 2014

[48] Tsoi H, Yu AC, Chen ZS, Ng NK, Chan AY, Yuen LY, Abrigo JM, Tsang SY, Tsui SK, Tong TM, Lo IF, Lam ST, Mok VC, Wong LK, Ngo JC, Lau KF, Chan TF, Chan HY. "A novel missense mutation in CCDC88C activates the JNK pathway and causes a dominant form of spinocerebellar ataxia," J Med Genet., 51(9), pp. 590595, 2014.

[49] Coutelier M, Blesneac I, Monteil A, Monin ML, Ando K, Mundwiller E, Brusco A, Le Ber I, Anheim M, Castrioto A, Duyckaerts C, Brice A, Durr A, Lory P, Stevanin G. "A Recurrent Mutation in CACNA1G
Alters Cav3.1 T-Type Calcium-Channel Conduction and Causes Autosomal-Dominant Cerebellar Ataxia," Am J Hum Genet., 97(5), pp. 726-737, 2015.

[50] Li SH, McInnis MG, Margolis RL, Antonarakis SE, Ross CA. "Novel triplet repeat containing genes in human brain: cloning, expression, and length polymorphisms," Genomics., 16(3), pp. 572-579, 1993.

[51] Powell A, Chandrasekharan S, Cook-Deegan R. "Spinocerebellar ataxia: patient and health professional perspectives on whether and how patents affect access to clinical genetic testing," Genet Med., 12(4 Suppl), pp. S83-S110, 2010.

[52] Potter NT, Nance MA; “Ataxia Molecular Diagnostic Testing Group. Genetic testing for ataxia in North America,” Mol Diagn., 5(2), pp. 91-99, 2000.

[53] Kim JY, Park SS, Joo SI, Kim JM, Jeon BS. "Molecular analysis of Spinocerebellar ataxias in Koreans: frequencies and reference ranges of SCA1, SCA2, SCA3, SCA6, and SCA7," Mol Cells., 12(3), pp. 336341, 2001.

[54]Gestinari RS, Duarte SF, Pimentel MM, Lima MA. "Genetic polymorphism of MJD1 alleles and molecular analysis of SCA3 patients from Rio de Janeiro, Brazil," Genet Test.; 8(3):281-285, 2004.

[55] Johnson J, Wood N, Giunti P, Houlden H. "Clinical and genetic analysis of spinocerebellar ataxia type 11," Cerebellum., 7(2), pp. 159-164, 2008.

[56] Cao DH, Liu XL, Qiu GB. “Genotyping and prenatal diagnosis of a large spinocerebellar ataxia pedigree in northeastern China,” J Genet., 90(2), pp. 369-372, 2011.

[57] Lindblad K, Savontaus ML, Stevanin G, Holmberg M, Digre K, Zander C, Ehrsson H, David G, Benomar A, Nikoskelainen E, Trottier Y, Holmgren G, Ptacek LJ, Anttinen A, Brice A, Schalling M. "An expanded CAG repeat sequence in spinocerebellar ataxia type 7," Genome Res., 6(10), pp. 965-971, 1996.

[58] Martorell L, Pujana MA, Volpini V, Sanchez A, Joven J, Vilella E, Estivill X. "The repeat expansion detection method in the analysis of diseases with CAG/CTG repeat expansion: usefulness and limitations," Hum Mutat., 10(6), pp. 486-488, 1997.

[59] Lindblad K, Lunkes A, Maciel P, Stevanin G, Zander C, Klockgether $T$, Ratzlaff $T$, Brice A, Rouleau GA, Hudson T, Auburger G, Schalling M. "Mutation detection in Machado-Joseph disease using repeat expansion detection," Mol Med., 2(1), pp. 77-85, 1996.

[60] Margolis RL. "Dominant spinocerebellar ataxias: a molecular approach to classification, diagnosis, pathogenesis and the future," Expert Rev Mol Diagn., 3(6), pp. 715-732, 2003.

[61] Koutsis G, Pemble S, Sweeney MG, Paudel R, Wood NW, Panas M, Kladi A, Houlden H. "Analysis of spinocerebellar ataxias due to expanded triplet repeats in Greek patients with cerebellar ataxia," J Neurol Sci., 318(1-2), pp. 178-180, 2012.

[62] Dubourg O, Dürr A, Cancel G, Stevanin G, Chneiweiss H, Penet C, Agid Y, Brice A. "Analysis of the SCA1 CAG repeat in a large number of families with dominant ataxia: clinical and molecular correlations," Ann Neurol., 37(2), pp. 176-180, 1995.

[63] Tsai HF, Liu CS, Leu TM, Wen FC, Lin SJ, Liu CC, Yang DK, Li C, Hsieh M. "Analysis of trinucleotide repeats in different SCA loci in spinocerebellar ataxia

\section{Volume 5 Issue 12, December 2016}




\section{International Journal of Science and Research (IJSR) \\ ISSN (Online): 2319-7064}

Index Copernicus Value (2015): 78.96 | Impact Factor (2015): 6.391

patients and in normal population of Taiwan," Acta Neurol Scand., 109(5), pp. 355-360, 2004.

[64] Lau KK, Lam K, Shiu KL, Au KM, Tsoi TH, Chan AY, Li HL, Sheng B. "Clinical features of hereditary spinocerebellar ataxia diagnosed by molecular genetic analysis," Hong Kong Med J., 10(4), pp. 255-259, 2004.

[65] Dorschner MO, Barden D, Stephens K. "Diagnosis of five spinocerebellar ataxia disorders by multiplex amplification and capillary electrophoresis," J Mol Diagn., 4(2), pp. 108-113, 2002.

[66] Lin JX, Ishikawa K, Sakamoto M, Tsunemi T, Ishiguro T, Amino T, Toru S, Kondo I, Mizusawa H. "Direct and accurate measurement of CAG repeat configuration in the ataxin-1 (ATXN-1) gene by "dual fluorescence labeled PCR-restriction fragment length analysis"," J Hum Genet., 53(4), pp. 287-295, 2008.

[67] Biros I I, Forrest SM. "Duplex PCR for Autosomal Dominant Spinocerebellar Ataxia Testing: A Nonradioactive Rapid Screening Method," Mol Diagn., 3(4), pp. 223-227, 1998.

[68] Bauer PO, Kotliarova SE, Matoska V, Musova Z, Hedvicakova P, Boday A, Tomek A, Nukina N, Goetz P. "Fluorescent multiplex PCR--fast method for autosomal dominant spinocerebellar ataxias screening,". Genetika., 41(6), pp. 830-837, 2005.

[69] Hsieh M, Lin SJ, Chen JF, Lin HM, Hsiao KM, Li SY, Li C, Tsai CJ. "Identification of the spinocerebellar ataxia type 7 mutation in Taiwan: application of PCRbased Southern blot," J Neurol., 247(8), pp. 623-629, 2000.

[70] Ishige T, Sawai S, Itoga S, Sato K, Utsuno E, Beppu M, Kanai K, Nishimura M, Matsushita K, Kuwabara S, Nomura F. "Pentanucleotide repeat-primed PCR for genetic diagnosis of spinocerebellar ataxia type 31," J Hum Genet., 57(12), pp. 807-808, 2012.

[71] Krysa W, Rajkiewicz M, Sułek A. "Rapid detection of large expansions in progressive myoclonus epilepsy type 1 , myotonic dystrophy type 2 and spinocerebellar ataxia type 8," Neurol Neurochir Pol., 46(2), pp. 113-120, 2012.

[72] Condorelli DF, Trovato-Salinaro A, Spinella F, Valvo S, Saponara R, Giuffrida S. "Rapid touchdown PCR assay for the molecular diagnosis of spinocerebellar ataxia type 2,” Int J Clin Lab Res., 28(3), pp. 174-178, 1998.

[73] Shakkottai VG, Fogel BL. "Clinical neurogenetics: autosomal dominant spinocerebellar ataxia," Neurol Clin., 31(4), pp. 987-1007, 2013.

[74] Storey E. "Non-Ataxic Presenting Symptoms of Dominant Ataxias," Cerebellum., 15(1), pp. 26-29, 2016.

[75] Lazarev VF, Benken KA, Semenyuk PI, Sarantseva SV, Bolshakova OI, Mikhaylova ER, Muronetz VI, Guzhova IV, Margulis BA. "GAPDH binders as potential drugs for the therapy of polyglutamine diseases: design of a new screening assay," FEBS Lett., 589(5), pp. 581-587, 2015.

[76] Nakamura K, Mieda T, Suto N, Matsuura S, Hirai H. "Mesenchymal stem cells as a potential therapeutic tool for spinocerebellar ataxia," Cerebellum., 14(2), pp. 165170, 2015.

[77] Jin JL, Liu Z, Lu ZJ, Guan DN, Wang C, Chen ZB, Zhang J, Zhang WY, Wu JY, Xu Y. "Safety and efficacy of umbilical cord mesenchymal stem cell therapy in hereditary spinocerebellar ataxia," Curr Neurovasc Res., 10(1), pp. 11-20, 2013.

[78] Bavarsad Shahripour R, Harrigan MR, Alexandrov AV. "N-acetylcysteine (NAC) in neurological disorders: mechanisms of action and therapeutic opportunities," Brain Behav., 4(2), pp. 108-122, 2014.

[79] Eldridge R, Iivanainen M, Stern R, Koerber T, Wilder BJ. "“"Baltic" myoclonus epilepsy: hereditary disorder of childhood made worse by phenytoin," Lancet., 2(8354), pp. 838-842, 1983.

[80] Tan S, Wang RH, Niu HX, Shi CH, Mao CY, Zhang R, Song B, Sun SL, Liu XJ, Hou HM, Liu YT, Gao Y, Fang H, Kong XD, Xu YM. "Nerve growth factor for the treatment of spinocerebellar ataxia type 3: an openlabel study," Chin Med J (Engl)., 128(3), pp. 291-294, 2015.

[81] Bushart DD, Murphy GG, Shakkottai VG. Precision medicine in spinocerebellar ataxias: treatment based on common mechanisms of disease. Ann Transl Med., 4(2), pp. 25, 2016.

\section{Author Profile}

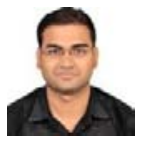

Pushpendra Mani Mishra received the Bachelor of Technology in Genetic Engineering from SRM University, Chennai in 2013 and Master of Technology in Biotechnology from Delhi Technological University, Delhi in 2016. He has past research experience from Emerging Pathogen Institute, University of Florida, USA and Institute of Genomics and Integrative Biology-CSIR, New Delhi, India.

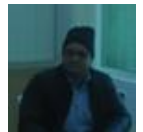

Dr. Vimal Kishor Singh, O/I, Stem Cell Research Laboratory, Department of Biotechnology, Delhi Technological University, Delhi, India

\section{Volume 5 Issue 12, December 2016

